Egyptian Journal of Aquatic Biology \& Fisheries

Zoology Department, Faculty of Science,

Ain Shams University, Cairo, Egypt.

ISSN $1110-6131$

Vol. 24(3): 125 - 144 (2020)

www.ejabf.journals.ekb.eg

\title{
GC/MS spectroscopic approach, antimicrobial activity and cytotoxicity of some marine macroalgae from Qusier and Marsa Alam Seashore (Red Sea), Egypt
}

\author{
Doaa A. Abdelrheem ${ }^{1}$, Aziz A. Rahman', Khaled N. M. Elsayed ${ }^{3}$, \\ Sayed A. Ahmed ${ }^{1, *}$
}

1- Department of Chemistry, Faculty of Science, Bani-Suef University 62511, Egypt

2- Department of Pharmacy, University of Rajshahi, Rajshahi-6205, Bangladesh

3- Department of Botany and Microbiology, Faculty of Science, Bani-Suef University, Egypt

*Corresponding Author: Sayed.hassan@ science.bsu.edu.eg

\section{ARTICLE INFO}

Article History:

Received: March 22, 2020

Accepted: April 28, 2020

Online: May 2020

Keywords:

Halimeda tuna

Padina gymnospora

Phacelocarpus tristichus

GC-MS

Antimicrobial activity

Cytotoxicity

\section{ABSTRACT}

In the present work, three macroalgae viz; Halimeda tuna, Padina gymnospora and Phacelocarpus tristichus, collected from Egyptian Red Sea shores were investigated for their chemical composition and pharmacological properties. Volatile compounds of $70 \%$ methanol extracts of three selected algae were analyzed by GC-MS. Antimicrobial and cytotoxic activities of algal extracts ( $70 \%$ methanol) were tested by agar well diffusion and in vitro cell viability assays, respectively. $P$. gymnospora showed the maximum antibacterial activity against $E$. coli $(13.90 \pm 0.66$ $\mathrm{mm})$, followed by $P$. tristichus $(12.97 \pm 0.65 \mathrm{~mm})$, while $H$. tuna inhibited significantly the growth of $S$. aureus $(13.17 \pm 0.67 \mathrm{~mm})$. Furthermore, the highest antifungal activity was obtained by $P$. gymnospora, followed by $P$. tristichus and finally $H$. tuna against $C$. neoformas and A. fumigatus. Also, $P$. gymnospora showed more cytotoxicity against HepG-2 and MCF-7 cell lines than $P$. tristichus and $H$. tuna. Moreover, it is the first report of chemical composition, antimicrobial activity and cytotoxicity of $P$. tristichus and also this research showed new reports on cytotoxicity of $P$. gymnospora and $H$. tuna against new cell lines. In conclusion, the Egyptian marine macroalgae possess antimicrobial and cytotoxic activities, that could be investigated for future application in medicine and recognizing novel drugs from the marine resources after checking their bioavailability in vivo.

\section{INTRODUCTION}

Recently, attention is placed on possible discovery of drugs from natural source rather than synthetic chemicals (Blunt et al., 2017). Marine algae or seaweeds are one of the natural resources essentially for producing various bioactive secondary metabolites with potential for use in the development of new pharmaceutical and industrial agents (Rico et al., 2017). Macroalgae are mainly classified into three taxonomic groups depend 
on pigmentation, these are green algae (Chlorophyta), red algae (Rhodophyta) and brown algae (Phaeophyta) (Pereira, 2010).

Several research studies have shown that macroalgae play a significant role in pharmaceutical industry due to their ability to produce secondary metabolites with a broad range of pharmacological activities, such as anti-inflammatory, antioxidant, antimicrobial, cytotoxicity, antiviral and anticoagulant activities (Al-Enazi $\boldsymbol{e t}$ al., 2018a). As an aid to protect themselves against other organisms in their environment, macroalgae produce various bioactive metabolites including, phlorotannins, polyketides, sterols, cyclic peptide, alkaloids, polysaccharide, diterpenoids, quinones, glycerols and lipids that have a wide range of biological activities (Al-Saif et al., 2014).

Halimeda tuna and Padina gymnospora are members of green and brown macroalgae, respectively. These macroalgae have already been studied for antimicrobial activity, but a very few results were obtained regarding their chemical composition and cytotoxicity (Araujo et al., 2013; Murugan \& Iyer, 2014; Milović et al., 2017; Madkour et al., 2019). Moreover, there is no specific report about chemical and biological properties of red alga Phacelocarpus tristichus.

The algal richness of Egyptian Red Sea coasts is undeniable in terms of diversity and quantity. However, there have been only a few studies on the pharmacological effects and chemical composition of the marine algae in this region (Madkour et al., 2019). Therefore, this study was designed to determine chemical composition, antimicrobial activity against nine microbial strains and cytotoxicity against two human cancer cell lines (HepG-2 and MCF-7) of the total $\mathrm{MeOH}$ (70\%) extracts obtained from three macroalgae viz; Halimeda tuna, Padina gymnospora and Phacelocarpus tristichus, collected from Egyptian Red Sea shores. It is worth mentioning that, this study is the first report of evaluating the chemical and biological properties of the red alga Phacelocarpus tristichus. Besides, our investigation showed new reports on cytotoxicity of $P$. gymnospora and $H$. tuna against new types of cell lines.

\section{MATERIALS AND METHODS}

\section{Algal samples}

Algal samples of Halimeda tuna, Padina gymnospora and Phacelocarpus tristichus were collected from Quseir and Marsa Alam at the Red Sea shores in Egypt in (2016-2017) (Figure 1). The voucher specimen of the algae was deposited at the Department of Chemistry, Faculty of Science, Beni-Suef University, Egypt. The identification of the collected algae was done by Dr. Khaled NM Elsayed, Associate Professor of algal biotechnology at Botany and Microbiology Department, Faculty of Science, Beni-Suef University, Egypt. 
Halimeda tuna

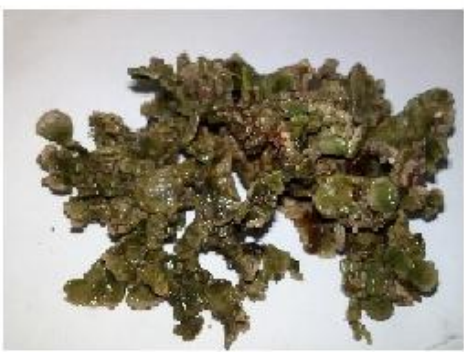

Padina gymnospora

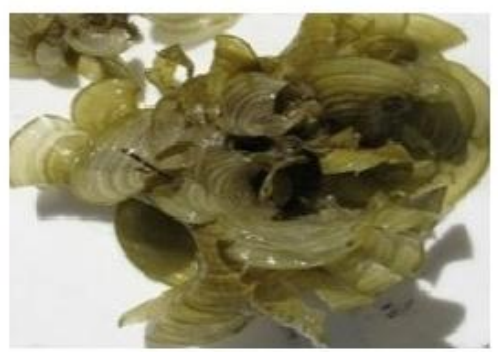

Phacelocarpus tristichus

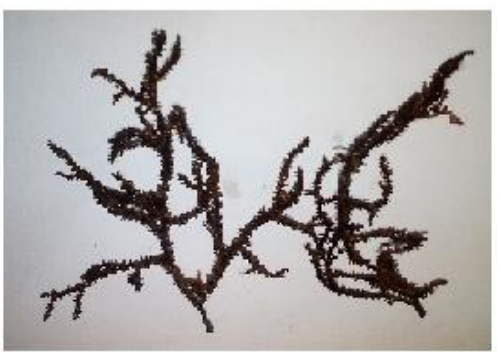

Figure 1: Marine algae collected from the Red Sea (Qusier and Marsa-Allam, Egypt).

\section{Preparation of the algal extracts}

The air-dried powdered algal samples (50 g each) were macerated in $70 \%$ methanol $(500 \mathrm{ml})$ for 3 days with regular shaking. After evaporation of solvent under reduced pressure, each extract of $H$. tuna $(0.51 \mathrm{~g}), P$. gymnospora $(1.53 \mathrm{~g})$ and $P$. tristichus $(1.4 \mathrm{~g})$ were stored at $-20{ }^{\circ} \mathrm{C}$ until further use.

\section{GC-MS analysis of algal extracts}

The analysis of chemical constituents present in the total extracts (70\% methanol) of $H$. tuna, $P$. gymnospora and $P$. tritichus were achieved by gas chromatography-mass spectrometry at the Regional Center for Mycology and Biotechnology (RCMB), AlAzhar University, Egypt, utilizing a DB5-MS column [30 $\mathrm{m} \times 0.25 \mathrm{~mm}$ ID (J\&W Scientific, USA)] with $1 \mathrm{~mL} / \mathrm{min}$ flow of helium as carrier gas. The WILEY \& NIST (National Institute of Standards and Technology, Gaithersburg, MD, USA) libraries were used for recognition of the main peaks (Araujo et al., 2013).

\section{Antimicrobial activity}

\section{Microbial strains}

The extracts (70\% methanol) of selected algae were subjected for their antimicrobial activity against nine micro-organisms. Three Gram positive bacteria Streptococcus mutans [RCMB 017 (1), ATCC 25175], Bacillus subtilis [RCMB 015 (1), NRRL B-543] and Staphylococcus aureus [RCMB010010], three Gram negative bacteria Enterobacter cloaca [RCMB 001 (1), ATCC 23355], Salmonella typhimurium [RCMB 006 (1), ATCC 14028] and Escherichia coli [RCMB 010052, ATCC 25955] and three fungi Candida albicans [RCMB 005003 (1), ATCC 10231], Cryptococcus neoformans [RCMB 0049001] and Aspergillus fumigates [RCMB 002008] were selected for the experiment. Microbial pathogens were got from the Regional Center for Mycology and Biotechnology (RCMB), Al-Azhar University, Egypt.

\section{Antimicrobial assay}

Antimicrobial activity of algal extracts was determined by agar well diffusion technique following National Committee for Clinical Laboratory Standards (NCCLS) (National Committee for Clinical Laboratory Standards, 2006). Algal extracts were 
dissolved in $5 \mathrm{mg} / \mathrm{mL}$ of dimethyl sulfoxide (DMSO, Merck), following control agents that were used, positive control agents: gentamycin $(10 \mu \mathrm{g} / \mathrm{mL}$ ) (for bacteria) and ketoconazol $(20 \mu \mathrm{g} / \mathrm{mL}$ ) (for fungi) as well as negative control agent: $5 \%$ DMSO. Mueller-Hinton agar was utilized as a culture media for bacteria and sabouraud dextrose agar was utilized for fungi. The tested algal extracts and controls $(100 \mu \mathrm{l})$ were dispensed into the wells (diameter $6 \mathrm{~mm}$ ). Plates were incubated for $24 \mathrm{~h}$ at $37^{\circ} \mathrm{C}$ for bacteria and for 3 days at room temperature for fungi; all cultures were kept under aerobic conditions. The diameters of the growth inhibition zones were measured in $\mathrm{mm}$. The experiments were realized in triplicates.

\section{Cytotoxic activity}

\section{Cells and propagation}

HepG-2 cells (human hepatocellular carcinoma) and MCF-7 cells (human breast carcinoma) were brought from VACSERA tissue culture unit, Cairo University, Egypt. Cells were kept in a $5 \% \mathrm{CO}_{2}$ atmosphere at $37{ }^{\circ} \mathrm{C}$. The cancer cells were grown in RPMI1640 medium involving $10 \%$ fetal bovine serum, HEPES buffer, 50 $\mu \mathrm{g} / \mathrm{ml}$ gentamycin and $1 \%$ L-glutamine (all purchased from Lonza).

\section{Cell viability assay}

The cells were plated in 96-well microplates (Falcon, NJ, USA) at concentration of $\left(1 \times 10^{4}\right.$ cells/well $)$ in $100 \mu \mathrm{l}$ of culture medium, and were allowed to stick for $24 \mathrm{~h}$ before treatment. Then, different concentrations of tested algal extracts in DMSO were added. $0.1 \%(\mathrm{v} / \mathrm{v})$ was the maximum concentration of DMSO in wells where DMSO was used as a solvent for all the tested extracts which showed no effect on the test. Doxorubicin $\mathrm{HCl}$ (Sigma-Aldrich) was used as reference drug positive control tested at the same concentrations used for the tested extracts. The cells were incubated for $24 \mathrm{~h}$ in the presence and absence of tested samples. Cytotoxicity was evaluated by a colorimetric method where (1\%) crystal violet solution was added to culture media for at least 30 minutes and then glacial acetic acid (30\%) was added. Then, absorbance was measured on micro-plate reader (Sun Rise, TECAN, Inc, USA), at wavelength $490 \mathrm{~nm}$. (Gomha $\boldsymbol{e t}$ al., 2015)

\section{Statistical analysis}

For antimicrobial activity: All the data were illustrated as means \pm standard deviation (SD). The procedures were carried out in triplicates.

For cytotoxicity: The $50 \%$ inhibitory concentration $\left(\mathrm{IC}_{50}\right)$ was obtained by nonlinear regression curve utilizing Graph pad Prism software (San Diego, CA, USA).

\section{RESULTS AND DISCUSSION}

\section{Chemical composition of algal extracts}

The chemical components of $70 \%$ methanol extracts of $H$. tuna, P. gymnospora and $P$. tristichus were characterized by GC-MS analysis (Figure 2, Table 1(a-c)). 
Obviously, there were various classes of chemical compounds in three algal extracts such as fatty acids, esters, sterols, terpenes, alkaloids, hydrocarbons, aldehydes, etc. Major chemical constituents present in $H$. tuna extract were lup-20(29)-en-3á-ol, acetate (36.45\%), dibutyl phthalate (29.52\%), betulinaldehyde (4.26\%), cyclooctasiloxane, hexadecamethyl (3.36\%) and lupeol (3.02\%). While hexadecanoic acid, methyl ester (14.09\%), hexadecanoic acid (13.09\%), cis-13-octadecenoic acid, methyl ester (10.99\%), propanoic acid, 2-hydroxy-, ethyl ester (10.42\%), 1-pentanol (6.99\%), 2-pentanone, 4hydroxy-4-methyl (6.67\%), tetradecanoic acid (4.69\%) and di-(9-octadecenoyl)-glycerol (3.26\%) were the major components in P. gymnospora extract.

Moreover, $P$. tristichus extract contains the highest percentage of hexadecanoic acid, methyl ester (20.57\%), followed by 5, 8, 11, 14-eicosatetraenoic acid, methyl ester, (all-Z) (11.73\%), stigmasta-5,24(28)-dien-3á-ol, (Z) (10.01\%), methyl-9-octadecenoate $(9.31 \%)$, methyl stearidonate $(8.81 \%)$, trans-9-octadecenoic acid $(4.70 \%)$, hexadecanoic acid $(4.41 \%)$ and cis-5,8,11,14,17-eicosapentaenoic acid (3.82\%) as major components.

Previous studies on the chemical constituents of $H$. tuna are limited (Shahnaz \& Shameel, 2006; Milović et al., 2017; Milović et al., 2019). The methanol extracts of Caulerpa scalpelliformis, Halimeda tuna and Udotea indica from Karachi coast in Pakistan were distinguished by high amount of saturated fatty acids (61-77\%) than unsaturated fatty acids (23-39\%) with the most predominant palmitic acid and oleic acid as well as cholesterol is the common sterol in three algal extracts (Shahnaz \& Shameel, 2006), whereas in our study, the $70 \%$ methanol extract of $H$. tuna contains the highest level of triterpenoids. In another study, the dichlorometane: methanol (1:1) dry extract of $H$. tuna from the Adriatic coast in Montenegro was characterized by high level of palmitic acid (32\%) and linoleic acid (13.63\%) with total 20 fatty acids (Milović et al., 2017). However, the cyclohexane extract of $H$. tuna from the same previous collected region was identified with its high percentage of $\beta$-sitosterol $(73.90 \pm 0.08 \mu \mathrm{g} / \mathrm{g})$ and low amount of campesterol $(3.78 \pm 0.12 \mu \mathrm{g} / \mathrm{g})$ as well as fatty acids with oleic acid, palmitic acid and $\alpha$ - linoleic acid as dominant fatty acids (Milović $\boldsymbol{e t}$ al., 2019). However, in our investigation, lup-20(29)-en-3á-ol, acetate (36.45\%) is the most dominant compound.

Likewise, there were a few studies about the chemical constituents of $P$. gymnospora (Al Easa et al., 1995; Murugan \& Iyer, 2014; Shanmuganathan \& Pandima, 2016; Vasanthi, 2016; Baliano et al., 2016; Ibraheem et al., 2017). Fucosterol is the predominant sterol in P. gymnospora from the coast of Qatar among total 4 identified sterols (Al Easa et al., 1995). Also, fucosterol (12.45\%) and L-(+)ascorbic acid-2,6-dihexadecanoate $(8.13 \%)$ were the most abundant compounds between total 16 compounds in $P$. gymnospora ethyl acetate extract from the coast of Tamil Nadu (Murugan \& Iyer, 2014). P. gymnospora from the intertidal region of the Gulf of Mannar was characterized by high percentage of stearic acid of total 7 fatty acids (Shanmuganathan \& Pandima, 2016). Oleic Acid (17.55\%), stigmasterol (15.89\%), trans-13-octadecenoic acid (8.69\%), n-hexadecanoic acid (6.23\%) and cis-vaccenic acid 
(4.72\%) were the main components in the hexane extract of P. gymnospora from Gulf of Mannar region (Vasanthi, 2016). From the bethonic area in Espirito Santo, $p$. gymnospora methanol extract contained eleven fatty acids among them linolenic, oleic, arachidonic and linoleic acids (Baliano et al., 2016). Palmitic acid (36.35\%) is the most predominant compound of total 9 fatty acids in the methanolic extract of $P$. gymnospora from Hurghada coastline, Red Sea, Egypt (Ibraheem et al., 2017). But, in our study, the $70 \%$ methanol of $P$. gymnospora showed the highest percentage of fatty acids and their esters with the most abundant hexadecanoic acid, methyl ester and hexadecanoic acid.

Obviously, our study showed that the identified major components of $70 \%$ methanol extracts of $H$. tuna and $P$. gymnospora are not similar with the previous reports from other extraction solvent and other countries. Variations in the chemical components of $H$. tuna and $P$. gymnospora can be due to different factors such as seasonal periods, geographical location, soil condition, extraction methods, analysis procedure, storage conditions, etc. (Pérez et al., 2016).

Moreover, this study is the first report about the chemical constituents of red alga $P$. tristichus, where its $70 \%$ methanol extract contained high level of esters of fatty acids, fatty acids and steroids with hexadecanoic acid, methyl ester and $\beta$-sitosterol as the most major compounds. In agreement to our study, red algae showed a variety of secondary metabolites as fatty acids, phenolics, phlorotannins, terpenes, polysaccharides, halogenated compounds, etc. (Alassali et al., 2016).
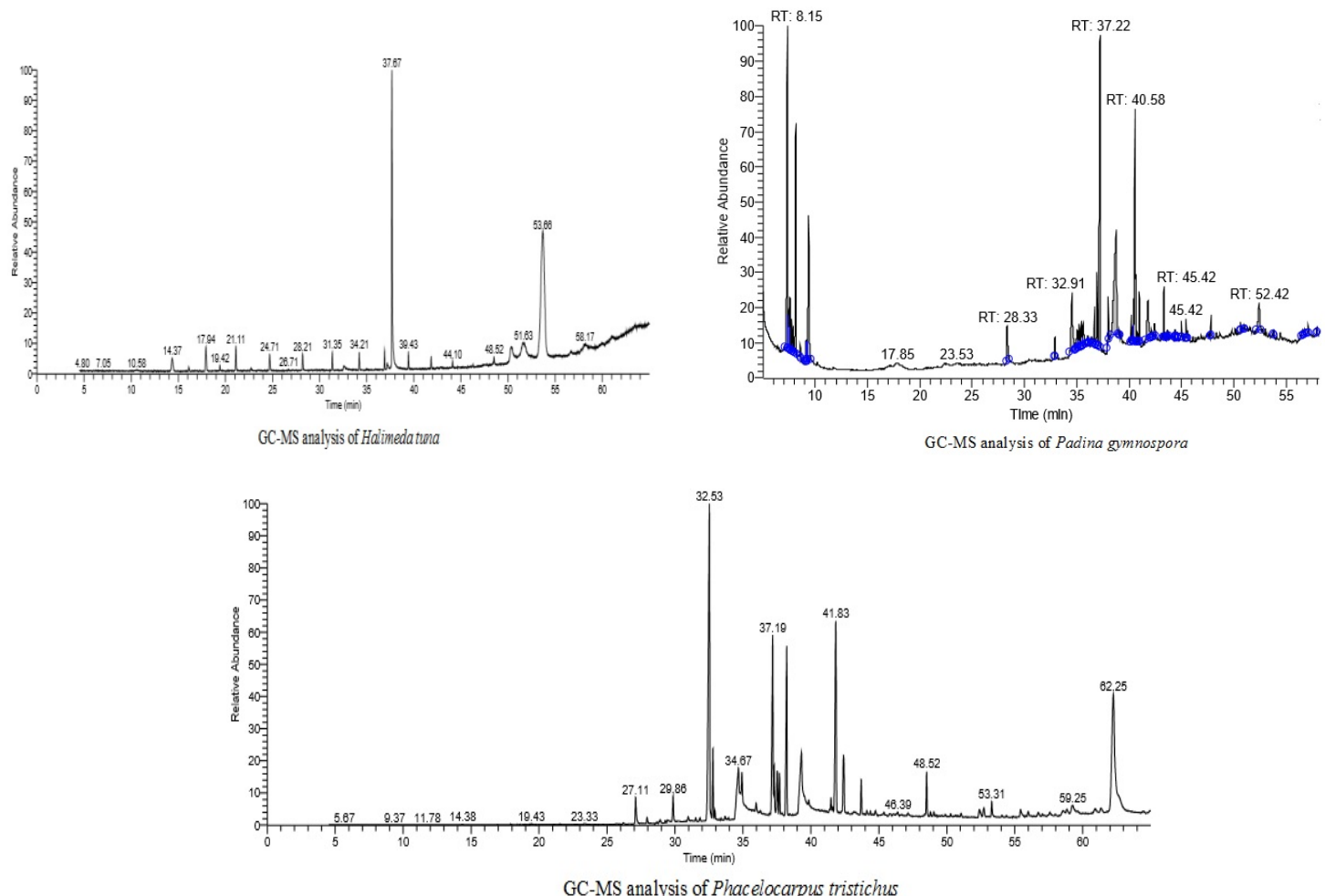

Figure 2: GC-MS chromatograms of $70 \%$ methanol extracts of three selected algae. 
Table 1(a): Major chemical constituents of $\mathrm{MeOH}(70 \%)$ extract of Halimeda tuna

\begin{tabular}{|c|l|c|c|c|c|}
\hline Serial n. & Compounds name & RT & Area (\%) & $\begin{array}{c}\text { Molecular } \\
\text { formula }\end{array}$ & $\begin{array}{c}\text { Molecular } \\
\text { weight }\end{array}$ \\
\hline $\mathbf{1}$ & Cyclooctasiloxane, hexadecamethyl & 17.94 & 3.36 & $\mathrm{C}_{16} \mathrm{H}_{48} \mathrm{O}_{8} \mathrm{Si}_{8}$ & 592 \\
\hline $\mathbf{2}$ & Dibutyl phthalate & 32.56 & 29.52 & $\mathrm{C}_{16} \mathrm{H}_{22} \mathrm{O}_{4}$ & 278 \\
\hline $\mathbf{3}$ & Lupeol & 37.67 & 3.02 & $\mathrm{C}_{30} \mathrm{H}_{50} \mathrm{O}$ & 426 \\
\hline $\mathbf{4}$ & Betulinaldehyde & 48.52 & 4.26 & $\mathrm{C}_{30} \mathrm{H}_{48} \mathrm{O}_{2}$ & 440 \\
\hline $\mathbf{5}$ & Lup-20(29)-en-3á-ol, acetate & 50.30 & 36.45 & $\mathrm{C}_{32} \mathrm{H}_{52} \mathrm{O}_{2}$ & 468 \\
\hline
\end{tabular}

Table 1 (b): Major chemical constituents of MeOH (70\%) extracts of Padina gymnospora

\begin{tabular}{|c|l|c|c|c|c|}
\hline Serial n. & Compound name & RT & Area (\%) & $\begin{array}{c}\text { Molecular } \\
\text { formula }\end{array}$ & $\begin{array}{c}\text { Molecular } \\
\text { weight }\end{array}$ \\
\hline $\mathbf{1}$ & Propanoic acid, 2-hydroxy-, ethyl ester & 7.34 & 10.42 & $\mathrm{C}_{5} \mathrm{H}_{10} \mathrm{O}_{3}$ & 118 \\
\hline $\mathbf{2}$ & 1-Pentanol & 8.15 & 6.99 & $\mathrm{C}_{5} \mathrm{H}_{12} \mathrm{O}$ & 88 \\
\hline $\mathbf{3}$ & 2-Pentanone, 4-hydroxy-4-methyl & 9.38 & 6.67 & $\mathrm{C}_{6} \mathrm{H}_{12} \mathrm{O}_{2}$ & 116 \\
\hline $\mathbf{4}$ & Tetradecanoic acid & 34.57 & 4.69 & $\mathrm{C}_{14} \mathrm{H}_{28} \mathrm{O}_{2}$ & 228 \\
\hline $\mathbf{5}$ & hexadecanoic acid, methyl ester & 37.22 & 14.09 & $\mathrm{C}_{17} \mathrm{H}_{34} \mathrm{O}_{2}$ & 270 \\
\hline $\mathbf{6}$ & Hexadecanoic acid & 38.79 & 13.09 & $\mathrm{C}_{16} \mathrm{H}_{32} \mathrm{O}_{2}$ & 256 \\
\hline $\mathbf{7}$ & cis-13-Octadecenoic acid, methyl ester & 40.58 & 10.99 & $\mathrm{C}_{19} \mathrm{H}_{36} \mathrm{O}_{2}$ & 296 \\
\hline $\mathbf{8}$ & Di-(9-octadecenoyl)-glycerol & 41.80 & 3.26 & $\mathrm{C}_{39} \mathrm{H}_{72} \mathrm{O}_{5}$ & 620 \\
\hline
\end{tabular}

Table 1(c): Major chemical constituents of MeOH (70\%) extract of Phacelocarpus tristichus

\begin{tabular}{|c|c|c|c|c|c|}
\hline Serial n. & Compound name & RT & Area $(\%)$ & $\begin{array}{c}\text { Molecular } \\
\text { formula }\end{array}$ & $\begin{array}{c}\text { Molecular } \\
\text { weight }\end{array}$ \\
\hline 1 & Hexadecanoic acid, methyl ester & 32.52 & 20.57 & $\mathrm{C}_{17} \mathrm{H}_{34} \mathrm{O}_{2}$ & 270 \\
\hline 2 & n-Hexadecanoic acid & 34.66 & 4.41 & $\mathrm{C}_{16} \mathrm{H}_{32} \mathrm{O}_{2}$ & 256 \\
\hline 3 & Methyl- 9-octadecenoate & $\begin{array}{c}r .1 \\
9\end{array}$ & 9.31 & $\mathrm{C}_{19} \mathrm{H}_{36} \mathrm{O}_{2}$ & 296 \\
\hline 4 & Methyl stearidonate & 38.22 & 8.81 & $\mathrm{C}_{19} \mathrm{H}_{30} \mathrm{O}_{2}$ & 290 \\
\hline 5 & trans-9-Octadecenoic acid & $\begin{array}{c}\text { rq. } \\
.\end{array}$ & 4.70 & $\mathrm{C}_{18} \mathrm{H}_{34} \mathrm{O}_{2}$ & 282 \\
\hline 6 & 5,8,11,14-Eicosatetraenoic acid, methyl ester, (all-Z) & 41.83 & 11.73 & $\mathrm{C}_{21} \mathrm{H}_{34} \mathrm{O}_{2}$ & 318 \\
\hline 7 & cis-5,8,11,14,17-Eicosapentaenoic acid & 42.41 & 3.82 & $\mathrm{C}_{20} \mathrm{H}_{30} \mathrm{O}_{2}$ & 302 \\
\hline 8 & Stigmasta-5,24(28)-dien-3á-ol, (Z) & 62.25 & 10.01 & $\mathrm{C}_{29} \mathrm{H}_{48} \mathrm{O}$ & 412 \\
\hline
\end{tabular}

\section{Antimicrobial activity}

Recently, microbial resistance to pharmaceutical drugs is on rise, which demands an alternate source of antibiotics against fatal diseases. Marine macroalgae are potential source of bioactive compounds making them one of the major subjects for the 
development of various pharmaceutical drugs. The present study revealed the antimicrobial activities of three algal extracts prepared by $70 \%$ methanol that were tested against nine micro-organisms (Table 2). The results showed that all three algal extracts exhibited relatively strong antimicrobial activity. These findings demonstrated that $70 \%$ methanol extracts contained significant amount of antimicrobial compounds. The finding is in agreement to our result by Rangaiah et al. (2010) that demonstrated that the methanolic extracts of seaweeds provided stronger antimicrobial activity than ethyl acetate and n-hexane extracts (Rangaiah et al., 2010). In contrast, Sastry and Rao (1994) showed that the chloroform extract exhibited the highest antimicrobial activity rather than the methanol and benzene extracts (Sastry \& Rao, 1994). This difference in the result probably because of many factors influenced the antimicrobial potency of marine macroalgae like the season and habitat of algal collection, different stages of plant growth, efficiency of extraction, resistance to the bacteria tested, etc. (Seenivasan $\boldsymbol{e t}$ al., 2010).

Consequently, the present study investigated that $P$. gymnospora exhibited the strongest antibacterial activity against $E$. coli $(13.90 \pm 0.66 \mathrm{~mm})$ followed by $P$. tritichus $(12.97 \pm 0.65 \mathrm{~mm})$. However, $H$. tuna showed potential antibacterial activity against $S$. aureu $(13.17 \pm 0.67 \mathrm{~mm})$. Additionally, the maximum antifungal activity $(16.20 \pm 0.17$ and $15.00 \pm 0.26 \mathrm{~mm}$ ) was established by $P$. gymnospora against $C$. neoformas and $A$. fumigatus, respectively. $H$. tuna reported the lowest antifungal activity against $A$. fumigatus $(7.98 \pm 0.18 \mathrm{~mm})$. It could be noticed from the present investigation that the methanol extract of P. gymnospora (Phaeophyceae) exhibited both the highest value and the broadest spectrum of antimicrobial activity among selected seaweeds against tested fungal and bacterial pathogens. In agreement to our results, Viachosi and Critchley (2001) investigated that the Phaeophyta extracts showed the strongest antimicrobial activity followed by the Rhodophyta and then the Chlorophyta (Viachosi \& Critchley, 2001).

In the current study, the fungal strains were more susceptible to $P$. gymnospora extract than bacterial strains where the highest inhibition zone $(16.20 \pm 0.17 \mathrm{~mm})$ was exhibited by $P$. gymnospora against $C$. neoformas. Also, strong antibacterial activity was observed for $P$. gymnospora extract with high potent against $E$. coli $(13.90 \pm 0.66 \mathrm{~mm})$ followed by $B$. subtilis $(12.10 \pm 0.75 \mathrm{~mm})$, S. aureus $(9.17 \pm 0.47 \mathrm{~mm})$ and $S$. typhimurium $(9.10 \pm 0.36 \mathrm{~mm})$. Similar findings were reported by Chander et al. (2014) who investigated that methanolic extract of $P$. gymnospora from India exhibited strong inhibition for the growth of most tested bacterial and fungal strains (Chander $\boldsymbol{e t}$ al., 2014). In contrast, Rosaline et al. (2012) showed that the methanolic extract of $P$. gymnospora and Sargassum wightii from the coastal Tamil Nadu in South India showed no inhibition zone against $B$. subtilis, S. aureus and E. coli as well as the acetone extract of these algae showed the most efficiency antimicrobial activity (Rosaline $\boldsymbol{e t}$ al., 2012). Also, Saliva et al. (2013) investigated that the ethanol extracts of Hypnea musciformes, 
P. gymnospora and Ulva fasciata from Pacheco showed stronger antimicrobial activity rather than methanol, hexane and acetone extracts in dissimilar to our results (Silva et al., 2013). These variations could be because of the different solubility behavior of secondary metabolites that could be influenced by seasonal and geographical distribution of the species (Rajasulochana et al., 2009).

In general, the antimicrobial activity of macroalgae is affected not only by natural factors as the environmental conditions, seasonality and the geographical location, but also antimicrobial phytoconstituents. Macroalgae contain a great variety of natural bioactive compounds with antimicrobial activity, like polyunsaturated fatty acids, phenolic compounds, carotenoids and polysaccharides. (Pérez et al., 2016)

The findings revealed that $70 \%$ methanol extract of $P$. gymnospora could be used as a prominent source of antimicrobial agent in pharmaceutical industry. This may be due to the presence of synergetic bioactive compounds intracellularly in $P$. gymnospora extract. From the data of GC-MS, hexadecanoic acid, methyl ester (14.09\%), hexadecanoic acid (13.09\%) and cis-13-octadecenoic acid, methyl ester (10.99\%) were the major compounds in crude extract of $P$. gymnospora. Previous studies showed that these secondary metabolites revealed several biological activities as antioxidant, antimicrobial, anti-inflammatory and cytotoxic activities (Pinto et al., 2017).

In addition, the results investigated that $H$. tuna exhibited the least antimicrobial activity against both bacterial and fungal strains especially $E$. coli $(9.03 \pm 0.55 \mathrm{~mm}), C$. neoformas $(8.33 \pm 0.29 \mathrm{~mm})$ and A. fumigatus $(7.98 \pm 0.18 \mathrm{~mm})$. In agreement with our results, Karthikaidev et al. (2009) showed that the ethanolic and chloroform extracts of $H$. tuna and Ulva reticulata from the coast of Vedalai, Gulf of Mannar, Tamilnadu exhibited a broad spectrum of antimicrobial activity compared to the methanolic extract (Karthikaidevi et al., 2009). In disagreement to our results, Indira et al. (2013) investigated that the methanol extract of $H$. tuna from India showed higher inhibition zone against the growth of tested micro-organisms than the chloroform and ethanol extracts (Indira et al., 2013). However, in the present study, H. tuna extract contained highly ratio of bioactive constituents as lup-20(29)-en-3á-ol, acetate (36.45\%) and dibutyl phthalate (29.52\%) according to GC-MS (Yusuf-Babatunde et al., 2019). This is weak antimicrobial activity of $H$. tuna probably because of the antagonistic effect of these compounds when they are found with each other in the H. tuna extract.

It is worth mentioned that, antimicrobial activity of red alga Phacelocarpus tristichus is reported for the first time in this study. The alga showed moderated antimicrobial activity among the selected algae. This is probably due to the synergetic bioactive compounds in P. tristichus extract. Hexadecanoic acid, methyl ester $(20.57 \%)$, stigmasta-5, 24(28)-dien-3-ol (10.01\%), 14-octadecenoic acid, methyl ester (9.31\%), methyl stearidonate $(8.81 \%), 5,8,11,14$-eicosatetraenoic acid, methyl ester $(11.73 \%)$ and hexadecanoic acid $(4.41 \%)$ were the major lipophilic components of $P$. tristichus according to GC-MS. The compounds were reported to possess antimicrobial, anti- 
inflammatory, antioxidant and cytotoxic activities (Lavanya \& Thangamathi, 2017). In agreement with our results, several studies reported that the methanol extract of red algae showed significant antimicrobial activity due to presence of lipophilic metabolites that have several pharmaceutical properties (Pérez et al., 2016; Ibraheem et al., 2017).

Our results indicated as well, the methanol extracts of $P$. gymnospora and $P$. tristichus were more effective as antifungal agents rather than bacterial agents when compared to H. tuna. This is evidence from the observation that the methanol extracts of the brown and red algae effectively inhibited most of the pathogens with the maximum inhibition zone of $(16.20 \pm 0.17 \mathrm{~mm})$ and $(14.43 \pm 0.45 \mathrm{~mm})$, respectively produced against C. neoformas. This is probably due to the difference in the composition and permeability of their cell wall. This observation is in accordance with many other studies, focused on antimicrobial activity that has investigated that structure and permeability of the cell wall are reasons for different sensitives in Gram positive bacteria, Gram negative bacteria and fungi (Albouchi et al., 2013; Kolanjinathan et al., 2014). In contrast, Ballestores et al. (1992) showed that $H$. tuna from Western Mediterranean exhibited strong antifungal properties (Ballesteros et al., 1992). This difference may be due to seasonal or location variations (Lima-Filho et al., 2002).

Also, the present study showed that a potent inhibitory activity of $P$. gymnospora extract was exactly observed on gram positive than on gram negative bacteria, except with $E$. coli that was highly affected with highest inhibition zone $(13.90 \pm 0.66 \mathrm{~mm})$. The strongest antibiotic activity of the brown algae against pathogens was supported by the recent findings of Manivannan et al. (2011) (Manivannan et al., 2011). Furthermore, the findings of the present investigation has brought to light that the methanol extract of $H$. tuna is more effective against Gram positive bacteria (S. aureus and B. subtilis) than Gram negative bacteria (E. cloaca). A similar observation was recorded by Wan et al. (2018) who found that Gram positive bacteria (B. subtilis, S. aureus and B. cereus) were the most sensitive bacteria to methanol extract of Halimeda sp. from the coastal area of Peninsular Malaysia, while Gram negative bacteria (E. coli and P. aeruginosa) and fungi (A. niger and C. albicans) were the most resistance to Halimeda sp. (Wan et al., 2018). In contrast, in this study, red algae extract of $P$. tristichus showed more effective against Gram negative bacteria (E. coli and S. typhimurium) compared to Gram positive bacteria (B. subtilis, S. aureus, and S. mutans).

The more susceptibility of a particular group of bacteria was because of the difference in their cell wall structure and their composition (Taskin et al., 2007). So, Gram positive bacteria were observed to be slightly more sensitive to both $P$. gymnospora and $H$. tuna extracts than Gram negative bacteria, possibly due to the hydrophilic cell wall structure of Gram negative bacteria (Silhavy et al., 2010). The cell wall of Gram negative bacteria is constituted mainly by a lipo-polysaccharide, which blocks the penetration of hydrophobic components of fatty acids, esters, steroids and terpenoids that are the major components of these tested seaweeds (Beveridge, 1999). 
However, the outer membrane of Gram negative bacteria act as a barrier to many environmental substances including antibiotics (Mendes et al., 2013), the higher susceptibility noticed with the $P$. tristichus extract gives a promising indication of developing a potent drug from this marine natural source to be utilized in combating the infections because of these pathogens. Previous studies reported that the high sensitivity for Gram negative strains than Gram positive strains is probably due to the presence of phenolic compounds in the tested extracts that solubilized the lipopolysaccharide layer of Gram negative cell wall, inducing the entry of the inhibitory molecules (Butkhup et al., 2010). However, other studies showed that phenolic extracts were more efficient against Gram positive bacteria (Klančnik et al., 2009). However, the methanol extract of red alga $P$. tristichus in our study contained highly percentage of lipophilic compounds and trace amounts of slightly hydrophilic compounds according to GC-MS; it is more effective against Gram negative bacteria than Gram positive bacteria. This higher inhibitory effect is probably because of synergetic effects of these compounds with Gram negative strains. In agreement with our results, Tchinda et al. (2019) investigated synergistic effects of combination of mixture of stigmasterol and $\beta$-sitosterol (lipophilic) with $\beta$-sitosterol-3-O- $\beta$-D-glucopyranoside (slightly hydrophilic) was observed in the inhibition of resistant Gram negative bacteria (Tchinda et al., 2019).

Table 2: Antimicrobial screening test of (70\% methanol) extracts of Halimeda tuna, Padina gymnospra and Phacelocarpus tritichus

\begin{tabular}{|c|c|c|c|c|c|c|c|c|c|}
\hline \multirow[t]{3}{*}{ Name of algae } & \multicolumn{9}{|c|}{ Inhibition zones (mm) } \\
\hline & \multicolumn{3}{|c|}{ Gram (+ve) bacteria } & \multicolumn{3}{|c|}{ Gram (-ve) bacteria } & \multicolumn{3}{|c|}{ Fungi } \\
\hline & S. aureus & B. subtilis & S. mutans & E. coli & S. typhimurium & E.cloaca & A. fumigatus & C. neoformas & C. albicans \\
\hline Halimeda tuna & $13.17 \pm 0.67$ & $10.10 \pm 0.46$ & $0.0 \pm 0.0$ & $9.03 \pm 0.55$ & $0.0 \pm 0.0$ & $0.0 \pm 0.0$ & $7.98 \pm 0.18$ & $8.33 \pm 0.29$ & $0.0 \pm 0.0$ \\
\hline P. gymnospora & $9.17 \pm 0.47$ & $12.10 \pm 0.75$ & $0.0 \pm 0.0$ & $13.90 \pm 0.66$ & $9.10 \pm 0.36$ & $0.0 \pm 0.0$ & $15.00 \pm 0.26$ & $16.20 \pm 0.17$ & $0.0 \pm 0.0$ \\
\hline P. tritichus & $0.0 \pm 0.0$ & $9.10 \pm 0.36$ & $0.0 \pm 0.0$ & $12.97 \pm 0.65$ & $11.10 \pm 0.36$ & $0.0 \pm 0.0$ & $13.93 \pm 0.15$ & $14.43 \pm 0.45$ & $0.0 \pm 0.0$ \\
\hline
\end{tabular}

Data are means of three replicates $(n=3) \pm$ standard error.

Gentamycin:control for gram (+ve) and gram (-) bacteria; Ketoconazol: control for fungi.

\section{Cytotoxicity}

Marine algae have showed several biological activities like cytotoxic and antitumor activities (Alves et al., 2018). In this study, the anti-proliferative activity of the $70 \%$ methanol extracts of $H$. tuna, P. gymnospora and $P$. tristichus was tested against HepG-2 and MCF-7 cell lines. Cell viability assay revealed a dose-dependent decline in percent viability of the cells. Here, all the cell lines were applied with different concentrations of algal extracts for $24 \mathrm{~h}$. The algal extract decreased the proliferation of liver and breast cancer cells after $24 \mathrm{~h}$ of incubation, presented in Table 3 and Figure 3. The tested algal extracts especially $P$. gymnospora extract showed the maximum cytotoxicity $(9.81$ and $11 \mu \mathrm{g} / \mathrm{mL})$, 
followed by $P$. tritichus (21 and $29.3 \mu \mathrm{g} / \mathrm{mL})$ and finally $H$. tuna $(22.4$ and $37.3 \mu \mathrm{g} / \mathrm{mL})$ against HepG-2 and MCF-7 cells, respectively.

Our results are the first published reports on the cytotoxic activity of red alga $P$. tristichus against HepG-2 and MCF-7 cell lines. However, there were a few reports on cytotoxicity of $P$. gymnospora and $H$. tuna, but our results are probably similar or contrary to these studies. These differences in the literature can be explained by the fact that the toxic effects of algae vary with the time of algae sampling and geological variations, solvent extraction and sampling protocol (Yamahara et al., 2015).

Milovic et al. (2017) found that significant cytotoxicity of the dichlorometane: methanol (1:1) dry extract of $H$. tuna from the Adriatic coast in Montenegro against human colon carcinoma cell line (LS174), human adenocarcinoma cell line (HeLa) and human chronic myelogenous leukaemia cell line (K562) (Milović et al., 2017). Kurt et al. (2014) showed that the methanol extract of $H$. tuna showed higher cytotoxicity against MCF-7 cell line than the chloroform extract because of increase in oxidative stress (Kurt et al., 2014). Moo-Puc et al. (2009) explored cytotoxicity of dichloromethane: methanol (7:3) extract of $H$. tuna from Yucatán in Mexico against MDCK (normal canine kidney), Hep-2 (human laryngeal carcinoma), KB (human nasopharyngeal carcinoma) and HeLa cells (Moo-Puc et al., 2009). Kurt et al. (2018) showed the cytotoxicity of methanol and chloroform extract of $H$. tuna against mouse neuroblastoma cell line (NA2B) due to the increase in oxidative stress (Kurt et al., 2018). Compared with their studies, the findings of this research show that this study is the first report of cytotoxicity of $H$. tuna against HepG-2 cell line and that the $H$. tuna methanol extract showed weak cytotoxicity. Similarly, as mentioned in antimicrobial activity, the antagonistic effects of bioactive compounds were observed in weak cytotoxicity of $H$. tuna against MCF-7 and HepG-2 cell lines.

Our results are the first published reports on cytotoxic activity of extract of brown alga P. gymnospora on MCF-7 and HepG-2 cell lines. Exceptionally, it has been shown that the aqueous extract of $P$. gymnospora synthesizes gold Nanoparticles of 53-67 nm which exhibited significant cytotoxicity against HepG2 and lung (A549) cells (Singh $\boldsymbol{e t}$ al., 2015). Obviously, there is difference between cytotoxic activity of nanoparticles composite with macroalgae and algae only where there are changes in cell viability, cell morphology and metabolic activity (Singh et al., 2015). Furthermore, others studies and findings reported the cytotoxicity of $P$. gymnospora from various location on other different cell lines (Koishi et al., 2012; Guedes et al., 2013; Murugan \& Iyer, 2013; Baliano et al., 2016; Sali, 2016; Gasparini et al., 2017). In the literature there is no data on cytotoxicity activity of $P$. gymnospora extract on HepG-2 and MCF-2 cells, but cytotoxic activity of some other algal extracts were studied on these cell lines by other researches. Mashjoor et al. (2016) found cytotoxicity for ethyl acetate extracts of Ulva flexuosa, Padina antillarum and Padina boergesen on MCF7, HeLa and Vero cell lines (Mashjoor et al., 2016). Al-Enazi et al. (2018b) reported a significant cytotoxicity of 
ethanol extract of Padina pavonica against A-549, Caco-2, HCT-116, Hela, HEp-2, HepG-2, and MCF-7 cell lines (Al-Enazi et al., 2018b). Compared with their results, the findings of this research suggest that the methanol extract of $P$. gymnospora showed potential cytotoxic effects.

In agreement with our results, several studies showed that brown seaweeds are probably good candidates for cancer therapies (Isnansetyo et al., 2017). Moreover, the higher significant cytotoxicity of $P$. gymnospora rather than other tested algal species probably because of the synergetic effect of bioactive metabolites of this algal extract that is illustrated previously. Thus, brown alga $P$. gymnospora is the promising source of therapeutic agent against micro-organisms and cancer disease.

Additionally, cytotoxicity of $P$. tristichus was determined against HepG-2 and MCF-7 cells for the first time. The findings reported that $P$. tristichus $\left(\mathrm{IC}_{50}\right.$ range 20-30 $\mu \mathrm{g} / \mathrm{mL}$ ) exhibited moderate cytotoxicity against both two cell lines as compared to the rest two algae. This significant cytotoxicity may be because of synergetic effects of bioactive metabolites with predominant fatty acids and sterols that are indicated by GCMS. In agreement with our results, Pacheco et al. (2018) showed that fatty acid extract of red alga Adenocystis utricularis has inhibitory effects against cancerous cells (Pacheco et al., 2018).

Table 3: In vitro cytotoxicity of $70 \%$ methanol extracts of three selected algae in two cell lines

\begin{tabular}{|l|c|c|}
\hline \multirow{2}{*}{\multicolumn{1}{|c|}{ Algae }} & \multicolumn{2}{c|}{ IC $_{\mathbf{5 0}}(\boldsymbol{\mu g} / \mathbf{m L})$} \\
\cline { 2 - 3 } & HepG-2 $_{1}$ & MCF-7 \\
\hline $\begin{array}{l}\text { Doxorubicin (standard } \\
\text { anti-cancer drug) }\end{array}$ & 0.36 & 0.35 \\
\hline Halimeda tuna & 22.4 & 37.3 \\
\hline Padina gymnospora & 9.80 & 11 \\
\hline Phacelocarpus tristichus & 21 & 29.3 \\
\hline
\end{tabular}

Two cell lines were treated with Doxorubicin as a positive control 

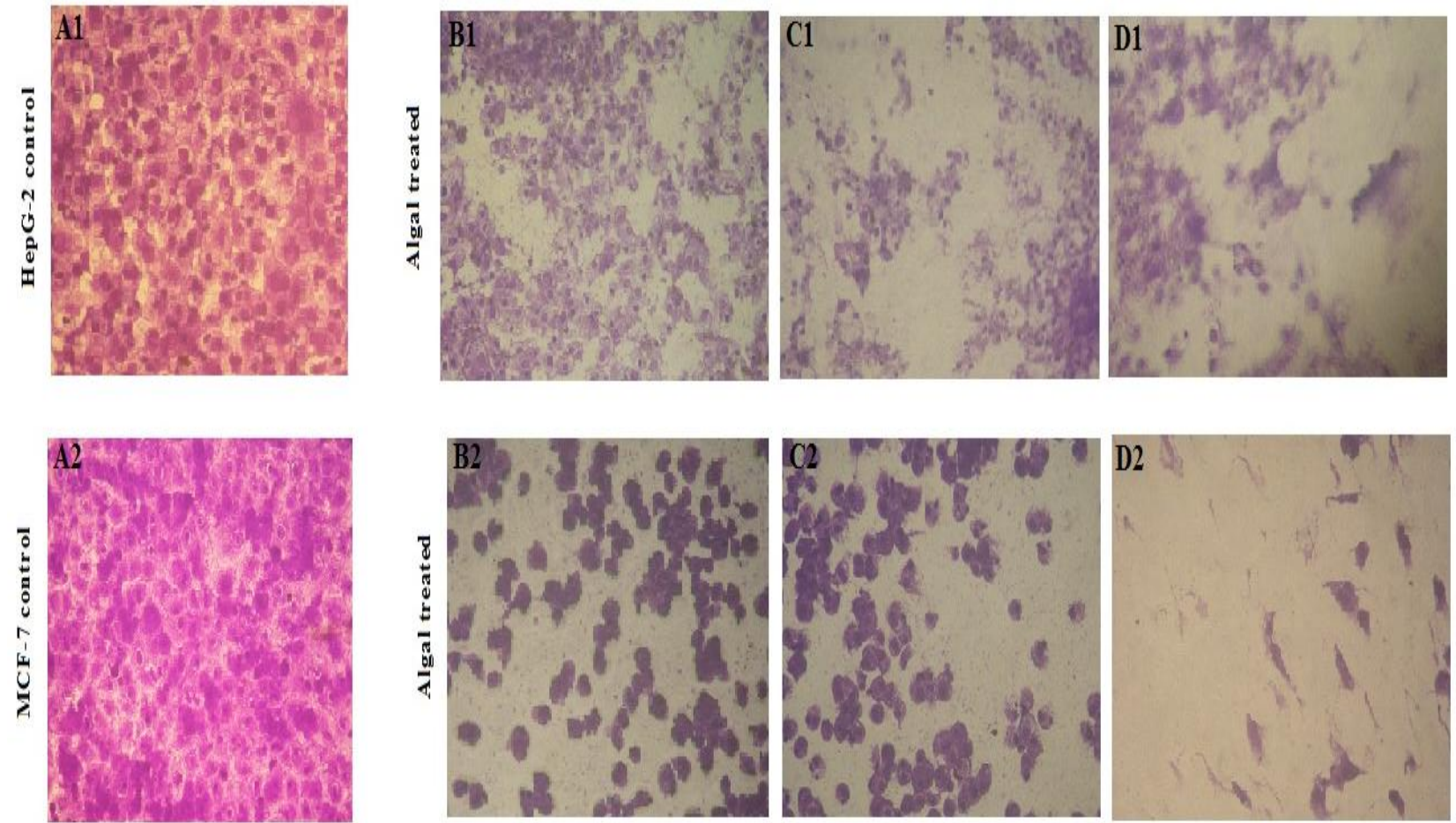

Figure 3: Photomicrograph of cell lines after $24 \mathrm{~h}$ of treatment with $70 \%$ methanol extracts of three selected algae at $125 \mu \mathrm{g} / \mathrm{mL}$ : (A1) HepG-2 control, (B1) HepG-2 treated with H. tuna extract, (C1) HepG-2 treated with $P$. gymnospora extract, (D1) HepG-2 treated with $P$. tristichus extract, (A2) MCF-7 control, (B2) MCF-7 treated with H. tuna extract, (C2) MCF-7 treated with $P$. gymnospora extract, (D2) MCF-7 treated with $P$. tristichus extract, all three selected algaetreated cell lines demonstrate shrinking and rounding of cells in contrast to control cells by different ratio.

\section{CONCLUSION}

The current study showed antimicrobial activity, cytotoxicity and GC-MS analysis for Halimeda tuna, Padina gymnospora and Phacelocarpus tristichus from Egyptian Red Sea shores. Where, the methanol (70\%) extract of $P$. gymnospora exhibited the highest antimicrobial and cytotoxicity followed by $P$. tristichus and finally $H$. tuna. Thus, these results identified the potential use of $P$. gymnospora extract as pharmaceutical agent of future drug that requires in vivo study for more confirmation. Moreover, our study is the first antimicrobial and cytotoxicity report of $P$. tristichus due to probably its bioactive metabolites screened by GC-MS analysis that is already reported for the first time. Thus, this research creates attention for further evaluation of biological studies and chemical constituents of Egyptian red alga phacelocarpus tritichus.

\section{REFERENCES}

Al-Enazi, N.M.; Awaad, A.S.; Alqasoumi, S.I. and Alwethairi, M.F. (2018 a).

Biological activities of the red algae Galaxaura rugosa and Liagora hawaiiana 
butters. Saudi Pharm. J., 26(1): 25-32. https://doi.org/https://doi.org/10.1016/j.jsps.2017. 11.003

Al-Enazi, N.M.; Awaad, A.S.; Zain, M.E. and Alqasoumi, S.I. (2018b). Antimicrobial, antioxidant and anticancer activities of Laurencia catarinensis, Laurencia majuscula and Padina pavonica extracts. Saudi Pharm. J., 26(1): 44-52.

Al-Saif, S.S.A.; Abdel-Raouf, N.; El-Wazanani, H.A. and Aref, I.A. (2014).

Antibacterial substances from marine algae isolated from Jeddah coast of Red sea, Saudi Arabia. Saudi J. Biol. Sci., 21(1): 57-64. https://doi.org/10.1016/j.sjbs.2013.06.001

Al Easa, H.S.; Kornprobst, J.M. and Rizk, A.M. (1995). Major sterol composition of some algae from Qatar. Phytochemistry, 39(2):373-374.

Alassali, A.; Cybulska, I.; Brudecki, G.P.; Farzanah, R. and Thomsen, M.H. (2016). Methods for upstream extraction and chemical characterization of secondary metabolites from algae biomass. Adv. Tech. Biol. Med., 1-16.

Albouchi, F.; Hassen, I.; Casabianca, H. and Hosni, K. (2013). Phytochemicals, antioxidant, antimicrobial and phytotoxic activities of Ailanthus altissima (Mill.) Swingle leaves. South Afr. J. Bot., 87: 164-174.

Alves, C.; Pinteus, S.; Rodrigues, A.; Horta, A. and Pedrosa, R. (2018). Algae from Portuguese coast presented high cytotoxicity and antiproliferative effects on an in vitro model of human colorectal cancer. Pharmacogn. Res., 10(1), 24. https://doi.org/10.4103/pr.pr_151_16

Araujo, G.S.; Matos, L.J.B.L.; Fernandes, J.O.; Cartaxo, S.J.M.; Gonçalves, L.R.B.; Fernandes, F.A.N. and Farias, W.R.L. (2013). Extraction of lipids from microalgae by ultrasound application: Prospection of the optimal extraction method. Ultrason. Sonochem., 20(1): 95-98. https://doi.org/10.1016/j.ultsonch.2012.07.027.

Baliano, A.P.; Pimentel, E.F.; Buzin, A.R.; Vieira, T.Z.; Romão, W.; Tose, L.V. and Kondratyuk, T.P. (2016). Brown seaweed Padina gymnospora is a prominent natural wound-care product. Rev. Bras. Farmacogn., 26(6): 714-719. https://doi.org/10.1016/j.bjp.2016.07.003

Ballesteros, E.; Martin, D. and Uriz, M.J. (1992). Biological activity of extracts from some Mediterranean macrophytes. Bot. Mar., 35(6): 481-486.

Beveridge, T.J. (1999). Structures of gram-negative cell walls and their derived membrane vesicles. J. Bacteriol., 181(16): 4725-4733.

Blunt, J.W.; Copp, B.R.; Keyzers, R.A.; Munro, M.H.G. and Prinsep, M.R. (2017). Marine natural products. Nat. Prod. Rep., 34(3): 235-294. https://doi.org/10.1039/c6np00124f

Butkhup, L.; Chowtivannakul, S.; Gaensakoo, R.; Prathepha, P. and Samappito, S. (2010). Study of the phenolic composition of Shiraz red grape cultivar (Vitis vinifera L.) cultivated in north-eastern Thailand and its antioxidant and antimicrobial activity. South Afr. J. Enol. Vitic., 31(2): 89-98.

Chander, M.P.; Veeraragavam, S. and Vijayachari, P. (2014). Antimicrobial and 
hemolytic activity of seaweed Padina gymnospora from South Andaman, Andaman and Nicobar Islands of India. Int. J. Curr. Microbiol. App. Sci., 3:364-369.

Gasparini, L.S.; Macedo, N.D.; Pimentel, E.F.; Fronza, M.; Junior, V.L.; Borges, W.S. and Lenz, D. (2017). In vitro cell viability by CellProfiler® software as equivalent to MTT assay. Pharmacogn. Mag., 13(2): S365.

Gomha, S.M.; Riyadh, S.M.; Mahmmoud, E.A. and Elaasser, M.M. (2015). Synthesis and anticancer activities of thiazoles, 1, 3-thiazines, and thiazolidine using chitosangrafted-poly (vinylpyridine) as basic catalyst. Heterocycles, 91(6): 1227-1243. Retrieved from doi: 10.3987/COM-15-13210

Guedes, É.A.C.; da Silva, T.G.; Aguiar, J.S.; de Barros, L.D.; Pinotti, L.M. and Sant'Ana, A.E. G. (2013). Cytotoxic activity of marine algae against cancerous cells. Rev. Bras. Farmacogn., 23(4): 668-673. https://doi.org/10.1590/S0102695X2013005000060

Ibraheem, B.M.I.; Hamed, S.M.; Abd Elrhman, A.A.; Farag, M.F. and AbdelRaouf, N. (2017). Antimicrobial activities of some brown macroalgae against some soil borne plant pathogens and in vivo management of Solanum melongena root diseases. Aust. J. Basic. Appl. Sci., 11:157-168.

Indira, K.; Balakrishnan, S.; Srinivasan, M.; Bragadeeswaran, S. and Balasubramanian, T. (2013). Evaluation of in vitro antimicrobial property of seaweed (Halimeda tuna) from Tuticorin coast, Tamil Nadu, Southeast coast of India. Afr. J. Biotechnol., 12(3). https://doi.org/10.5897/AJB12.014

Isnansetyo, A.; Lutfia, F.N.L.; Nursid, M. and Susidarti, R.A. (2017). Cytotoxicity of fucoidan from three tropical brown algae against breast and colon cancer cell lines. Pharmacogn. J., 9(1). https://doi.org/10.5530/pj.2017.1.3

Karthikaidevi, G.; Manivannan, K.; Thirumaran, G.; Anantharaman, P. and Balasubaramanian, T. (2009). Antibacterial properties of selected green seaweeds from Vedalai coastal waters; Gulf of Mannar Marine Biosphere Reserve. Global J. Pharmacol., 3(2), 107-112.

Klančnik, A.; Guzej, B.; Kolar, M.H.; Abramovič, H. and MOŽINA, S.S. (2009). In vitro antimicrobial and antioxidant activity of commercial rosemary extract formulations. J. Food Prot., 72(8): 1744-1752. https://doi.org/10.4315/0362-028X72.8 .1744

Koishi, A.C.; Zanello, P.R.; Bianco, É.M.; Bordignon, J. and dos Santos, C.N.D. (2012). Screening of Dengue virus antiviral activity of marine seaweeds by an in situ enzyme-linked immunosorbent assay. PLoS One, 7(12).

Kolanjinathan, K.; Ganesh, P. and Saranraj, P. (2014). Pharmacological importance of seaweeds: a review. World J. Fish Mar. Sci., 6(1): 1-15.

Kurt, O.; Özdal-Kurt, F.; Akçora, C.M.; Özkut, M. and Tuğlu, M.I. (2018). Neurotoxic, cytotoxic, apoptotic and antiproliferative effects of some marine algae extracts on the NA2B cell line. Biotech. Histochem., 93(1): 59-69. 
Kurt, O.; Özdal-Kurt, F.; Tuğlu, M.I. and Akçora, C.M. (2014). The cytotoxic, neurotoxic, apoptotic and antiproliferative activities of extracts of some marine algae on the MCF-7 cell line. Biotech. Histochem., 89(8): 568-576.

Lavanya M. and Thangamathi. P. (2017). PROPERTIES OF SEAWEEDS. A REVIEW. Int. J. Curr. Innov. Res., 3(10): 843-846.

Lima-Filho, J.V.M.; Carvalho, A.F.F.U.; Freitas, S.M. and Melo, V.M.M. (2002). Antibacterial activity of extracts of six macroalgae from the northeastern Brazilian coast. Braz. J. Microbiol., 33(4): 311-314. https://doi.org/10.1590/S1517$\underline{83822002000400006}$

Madkour, F.F.; El-Shoubaky, A.G. and Ebada, A.M. (2019). Antibacterial activity of some seaweeds from the Red Sea coast of Egypt. Egypt. J. Aquat. Biol. Fish., 23(2):265-274.

Manivannan, K.; Anantharaman, P. and Balasubramanian, T. (2011). Antimicrobial potential of selected brown seaweeds from Vedalai coastal waters, Gulf of Mannar. Asian Pac. J. Trop. Biomed., 1(2): 114-120. https://doi.org/10.1016/S22211691(11)60007-5

Mashjoor, S.; Yousefzadi, M.; Esmaeili, M.A. and Rafiee, R. (2016). Cytotoxicity and antimicrobial activity of marine macro algae (Dictyotaceae and Ulvaceae) from the Persian Gulf. Cytotechnology., 68(5): 1717-1726.

Mendes, M.; Pereira, R.; Pinto, I.S.; Carvalho, A.P. and Gomes, A.M. (2013). Antimicrobial activity and lipid profile of seaweed extracts from the North Portuguese Coast. Int. Food Res. J., 20(6): 3337.

Milović, S.; Kundaković, T.; Mačić, V.; Stanković, J. A.; Grozdanić, N.; Đuričić, I. and Stanojković, T. (2017). Anti $\alpha$-glucosidase, antitumour, antioxidative, antimicrobial activity, nutritive and health protective potential of some seaweeds from the Adriatic coast of Montenegro. Farmacia, 65(5): 731-740.

Milović, S.; Stanković, I.; Nikolić, D.; Radović, J.; Kolundžić, M.; Nikolić, V. and Kundaković-Vasović, T. (2019). Chemical Analysis of Selected Seaweeds and Seagrass from the Adriatic Coast of Montenegro. Chem. Biodivers., 16(10): e1900327. https://doi.org/10.1002/cbdv.201900327

Moo-Puc, R.; Robledo, D. and Freile-Pelegrín, Y. (2009). In vitro cytotoxic and antiproliferative activities of marine macroalgae from Yucatán, Mexico. Cienc. Mar., 35(4): 345-358.

Murugan, K. and Iyer, V.V. (2013). Differential growth inhibition of cancer cell lines and antioxidant activity of extracts of red, brown, and green marine algae. In Vitro Cell. Dev. Biol. Anim., 49(5): 324-334.

Murugan, K. and Iyer, V.V. (2014). Antioxidant activity and gas chromatographic-mass spectrometric analysis of extracts of the marine algae, Caulerpa peltata and Padina gymnospora. Indian J. Pharm. Sci., 76(6): 548. https://doi.org/10.4103/0250474X.147242 
National Committee for Clinical Laboratory Standards. (2006). Performance standards for antimicrobial disk susceptibility tests: approved standards. National Committee for Clinical Laboratory Standards(NCCL).

Pacheco, B.S.; dos Santos, M.A.Z.; Schultze, E.; Martins, R.M.; Lund, R.G.; Seixas, F.K. and De Pereira, C.M.P. (2018). Cytotoxic Activity of Fatty Acids From Antarctic Macroalgae on the Growth of Human Breast Cancer Cells. Front. Bioeng. Biotechnol., 6. Retrieved from doi: 10.3389/fbioe.2018.00185

Pereira, L. (2010). Littoral of Viana do Castelo-ALGAE: Uses in agriculture, gastronomy and food industry (Bilingual). Câmara Municipal de Viana Do Castelo: Viana Do Castelo.

Pérez, M.J.; Falqué, E. and Domínguez, H. (2016). Antimicrobial action of compounds from marine seaweed. Mar. Drugs, 14(3). https://doi.org/10.3390/md14030052

Pinto, M.E.A.; Araujo, S.G.; Morais, M.I.; Sá, N.P.; Lima, C.M.; Rosa, C.A. and Lima, L.A.R.S. (2017). Antifungal and antioxidant activity of fatty acid methyl esters from vegetable oils. An. Acad. Bras. Ciênc., 89(3): 1671-1681. https://doi.org/10.1590/0001-3765201720160908

Rajasulochana, P.; Dhamotharan, R.; Krishnamoorthy, P. and Murugesan, S. (2009). Antibacterial activity of the extracts of marine red and brown algae. J. Am. Sci., 5(3): 20-25.

Rangaiah, G.S.; Lakshmi, P. and Sruthikeerthi, K. (2010). Antimicrobial activity of the crude extracts of Chlorophycean seaweeds Ulva, Caulerpa and Spongomorpha sps. against clinical and phytopathogens. Drug Invent. Today, 2(6).

Rico, M.; González, A.G.; Santana-Casiano, M.; González-Dávila, M.; PérezAlmeida, N. and de Tangil, M.S. (2017). Production of primary and secondary metabolites using algae. In Prospects and Challenges in Algal Biotechnology (pp. 311-326). https://doi.org/https://doi.org/10.1007/978-981-10-1950-0_12

Rosaline, X.D.; Sakthivelkumar, S.; Rajendran, K. and Janarthanan, S. (2012). Screening of selected marine algae from the coastal Tamil Nadu, South India for antibacterial activity. Asian Pac. J. Trop. Biomed., 2(1):S140-S146.

Sali, V.K. (2016). Anticancer potential of selected marine algae of gulf of mannar Southeast coast of India. Pondicherry.

Sastry, V. and Rao, G.R.K. (1994). Antibacterial substances from marine algae: successive extraction using benzene, chloroform and methanol. Bot. Mar., 37(4): 357-360.

Seenivasan, R.; Indu, H.; Archana, G. and Geetha, S. (2010). The antibacterial activity of some marine algae from south east coast of India. J. Pharm. Res., 9(5):480-489.

Shahnaz, L. and Shameel, M. (2006). Phycochemistry and bioactivity of some siphonaceous green algae from Karachi coast [Pakistan]. Int. J. Phycol. Phycochem. (Pakistan), 2(2): 223-228. 
Shanmuganathan, B. and Pandima Devi, K. (2016). Evaluation of the nutritional profile and antioxidant and anti-cholinesterase activities of Padina gymnospora (Phaeophyceae). Eur. J. Phycol., 51(4):482-490. https://doi.org/https://doi.org/10.1080/09670262.2016.1218938

Silhavy, T.J.; Kahne, D. and Walker, S. (2010). The bacterial cell envelope. Cold Spring Harb. Perspect. Biol., 2(5): a000414.

Silva, G.C.; Albuquerque-Costa, R.; Oliveira-Peixoto, J.R.; Pessoa-Nascimento, F.E.; de Macedo-Carneiro, P.B. and dos Fernandes-Vieira, R.H.S. (2013).

Tropical Atlantic marine macroalgae with bioactivity against virulent and antibiotic resistant Vibrio. Lat. Am. J. Aquat. Res., 41(1): 183-188. https://doi.org/103856/vol41-issue1-fulltext-17

Singh, M.; Saurav, K.; Majouga, A.; Kumari, M.; Kumar, M.; Manikandan, S. and Kumaraguru, A.K. (2015). The cytotoxicity and cellular stress by temperature-fabricated polyshaped gold nanoparticles using marine macroalgae, Padina gymnospora. Biotechnol. Appl. Biochem., 62(3): 424-432. https://doi.org/10.1002/bab.1271

Taskin, E.; Ozturk, M. and Kurt, O. (2007). Antibacterial activities of some marine algae from the Aegean Sea (Turkey). Afr. J. Biotechnol., 6(24): 2746.

Tchinda, C.F.; Sonfack, G.; Simo, I.K.; Çelik, İ.; Voukeng, I.K.; Nganou, B.K. and Tane, P. (2019). Antibacterial and antibiotic-modifying activities of fractions and compounds from Albizia adianthifolia against MDR Gram-negative enteric bacteria. BMC Complement. Altern. Med., 19(1): 120. https://doi.org/10.1186/s12906-0192537-1

Vasanthi, H.R. (2016). Anticancer potential of selected marine algae of Gulf of Mannar (Southeast coast of India). Pondicherry university, India.

Viachosi, V. and Critchley, A.T.H.A. (2001). On the gras status of seaweeds. i. observations on the association between antibacterial activity of ethanolic extracts and meta1 levels present in selected seaweeds. Bull. Mar. Sci. Fish., Kochi Univ., 21: 7-12.

Wan, R.; Ernie, E.R.S.; Nor, F.; Abdul Rahim, Batrisyia, S.F. and Khairul. A. R. (2018). Antimicrobial activity of marine green algae extract against microbial pathogens. Malaysian J. Biochem. Mol. Biol., 2: 42-46.

Yamahara, K.M.; Demir-Hilton, E.; Preston, C.M.; Marin, R.; Pargett, D.; Roman, B. and Scholin, C.A. (2015). Simultaneous monitoring of faecal indicators and harmful algae using an in-situ autonomous sensor. Lett. Appl. Microbiol., 61(2): 130-138.

Yusuf-Babatunde, A.M.; Osuntokun, O.T.; Ige, O.O. and Solaja, O.O. (2019). Secondary metabolite Constituents, Antimicrobial Activity and Gas chromatography Mass spectroscopy Profile of Bombax buonopozense P. Beauv.(Bombacaceae) Stem bark Extract. Res. J. Pharmacogn. Phytochem., 11(2): 87-92. 


\section{ARABIC SUMMARY}

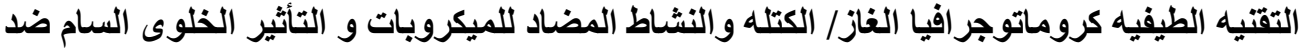
الخلاياالسرطانيه لبعض الطحالب البحرية الكبيره الموجودة على شؤاطى البحر الأحمر المصرية فى منطقى مرسى علم والقصير

دعاء عبد المنعم عبدالرحيم' ،عزيز عبدالرحمن '، خالا ناجح السيدّو سيد عبدالقادر أحمد'” 1- قسم الكيمياءـ كليه العطوم- جامعة بنى سويف ال1ه با - مصر

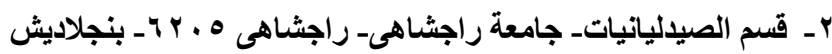

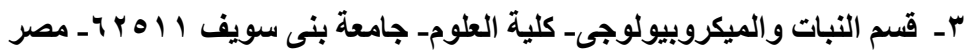

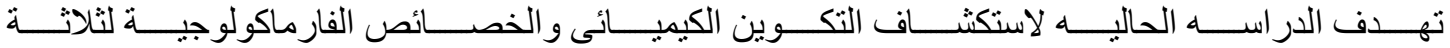
طحالسب كبيـرهوهــ: Halimeda tuna gymnospora , Padina tristichus

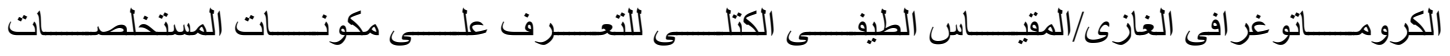

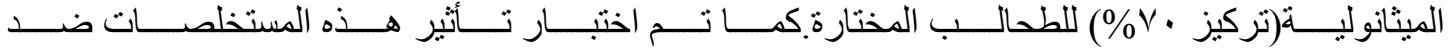

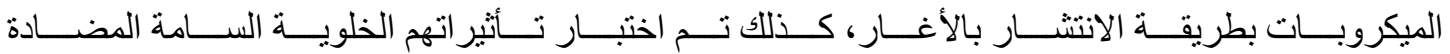

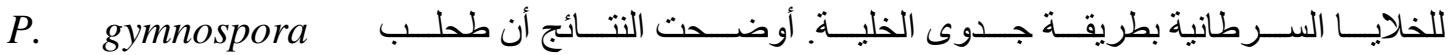

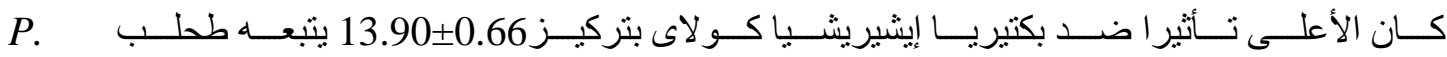

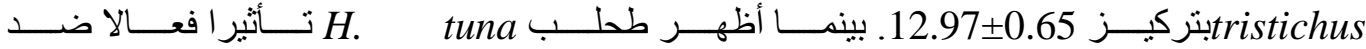

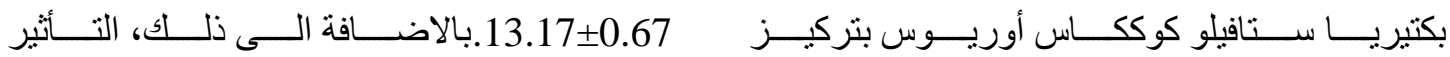

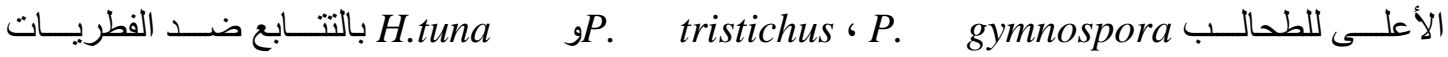

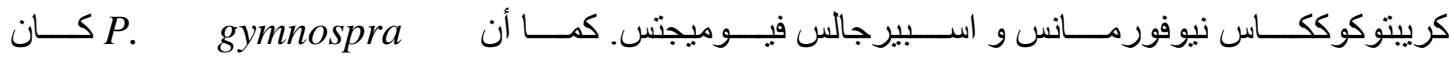

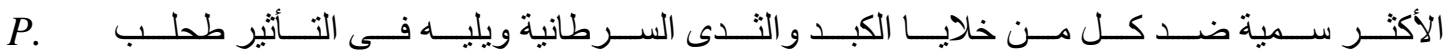

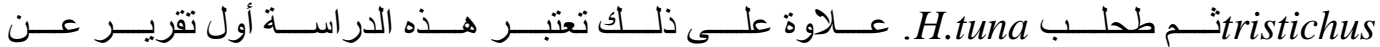

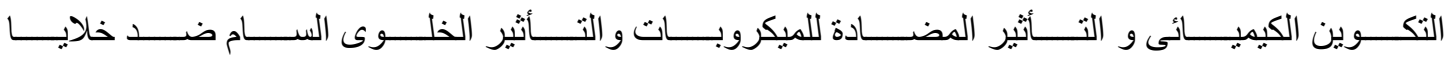

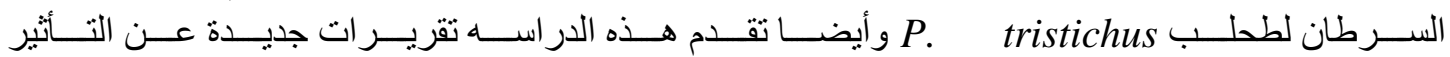

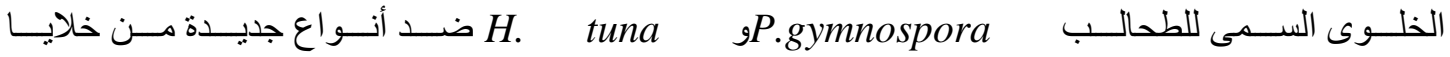

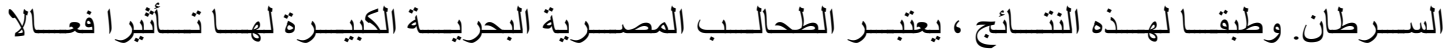

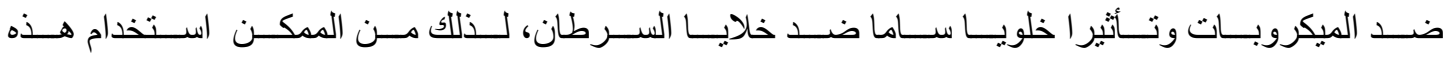

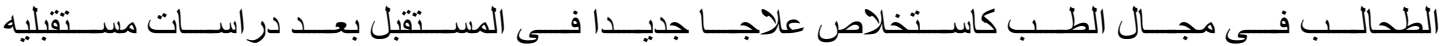

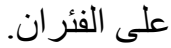

